\title{
:: Editorial
}

Revista Digital do LAV - Laboratório de Artes Visuais

Ano III - Número 04- Março de 2010. ISSN 1983-7348

Caros(as) Leitores (as)!

A Revista Digital do LAV tem publicações de caráter científico com periodicidade semestral, com ISSN, Conselho Editorial formado por trinta pareceristas de diferentes IES do Brasil e do exterior, com duas edições publicadas regularmente no período previsto e conforme edital semestral no site http://www.ufsm.br/lav

É com grande alegria que celebramos a publicação desta quarta edição como periódico avaliado pela CAPES, Nacional qualis B2 - Artes e Nacional qualis B5 - Educação. Desde o nascimento da revista contamos com artigos internacionais em todas as edições. Nesse sentido queremos agradecer as inúmeras contribuições dos autores de diferentes instituições do país e do exterior.

Recebemos para este número da revista trinta e dois artigos e uma resenha do Brasil e do exterior. Após análise do Conselho Editorial foram selecionados para publicação nove artigos. Sejam todos muito bem-vindos!

"O 'espaço' da arte contemporânea em contextos educativos: confluências e interferências sócio-culturais" é o artigo proposto por Kelly Bianca Clifford Valença. A pesquisa em pauta foi realizada durante os anos de 2007 e 2008 e é resultado da sua dissertação de Mestrado em Cultura Visual (UFG), defendida e aprovada em Abril de 2009. Kelly discute o papel docente frente à arte contemporânea.

Em "Conflitos e ambiguidades sobre diferença cultural: alguns impactos para a arte educação pós-moderna e a cultura visual" Raimundo Martins e Pablo Petit Passos Sérvio nos apresentam parte de investigação que está sendo desenvolvida no Programa de Pós-Graduação em Cultura Visual, Mestrado, Faculdade de Artes Visuais, Universidade Federal de Goiás na Linha de Pesquisa "Culturas da imagem e processos de mediação".

Thais Raquel da Silva Paz propõe o texto "Educação das artes visuais: corpo, subjetividades e diferenças na perspectiva da fotografia", artigo realizado durante a disciplina Estágio Curricular Supervisionado II do Curso de Licenciatura em Artes Visuais da UFSM/RS. Neste texto Thais aborda as questões sobre o corpo e a subjetividade do educando através da linguagem da fotografia no ensino de arte na escola.

"Trajetória artística de Alphonsus Benetti" é a contribuição de Luana de Siqueira Brasil e Ayrton Dutra Corrêa. Os autores nos apresentam a trajetória de um artista local, o também professor do Centro de Artes e Letras da UFSM - Alfonso Benetti, pintor conhecido nacional e internacionalmente pela sua produção pictórica. 
"El Proyecto Estampa y la política de la impresión: el grabado contemporáneo" é o texto escrito pelo artista uruguaio Gabriel Lema. Sua produção vincula-se a formação do coletivo "Proyecto Estampa" com antecedentes históricos da gravura na América do Sul. Destaca-se a multiplicidade da linguagem da gravura como forma de inserção da arte no contexto popular.

Lutiere Dalla Valle nos traz “¿Qué significa aprender desde Proyectos de Indagación?”. Como forma de refletir sobre seu processo investigativo e com base na perspectiva Construcionista e nos Estudos da Cultura Visual a partir dos Projetos de Trabalho Lutiere procura discutir a pesquisa que desenvolve no seu doutorado na Universidad de Barcelona, Espanha.

"Clement Greenberg pelo avesso" é a proposta de Vitor Butkus, fruto da pesquisa teórica desenvolvida no âmbito da disciplina Ciências da Arte: Teoria e Prática, sob a orientação da Profa. Dra. Mônica Zielinsky, no Instituto de Artes da UFRGS.

Flávia Dutra Cordeiro nos faz um convite com a proposição "Percorrendo o labirinto com Marcel Duchamp" onde amplia os conceitos desenvolvidos na sua Dissertação de Mestrado realizada na UFMG onde se encontra presente a relação sobre as obras do artista francês Marcel Duchamp associadas ao modelo contemporâneo de labirinto.

Em "Educação e arte: a consolidação de um campo interminável" o pesquisador e professor da PUC/RS Marcos Villela Pereira explora algumas considerações acerca da educação, da arte e da relação entre elas, de modo a mostrar a condição interminável desse campo de estudo e investigação.

Desejo a todos e a todas uma excelente leitura!

\section{Marilda Oliveira de Oliveira}

Presidente da Comissão Editorial

Revista Digital do LAV 